\title{
MR. FISHER'S REJOINDER TO MR. T. MELLARD READE.
}

Sir,-In my letter, at p. 431, on "The Permanence of Ocean Basins," I said that South Georgia might fairly be excluded from the category of Oceanic Islands, as having been perhaps formerly joined to South America. The bearing of this upon the question seems to me to be that, if it had not been formerly connected with some still existing continent, it might be argued that it had belonged to a submerged one. But if it formed once part of one now existing, that conclusion would not be necessary. Moreover, it stands a witness to the antiquity of South America, because of the length of time which must have been occupied in the destruction of the connecting land.

Thuse who believe in the doctrine of permanence do not assert that the continents have always had their present size or shapes, but only that, on the whole, they have not changed places with the oceans.

O. Fisher.

Harlton, Cambridge, 6 th Oot.

THE CLASSIFICATION OF THE JURASSIC SYSTEM.

Sir,-The Geological Magazine for July contained a short paper by Mr. Blanford on the Classification of Sedimentary Strata, with a Table, which ainued at the simplification of our present stratigraphical nomenclature. None of our geological systems stand more in need of revision and simplification than the Jurassic, and I think many will welcome the suggestion that this system should be divided into three sections or stages, and three only,-an Upper, Middle, and Lower, as Mr. Blanford proposes.

An Oolitic system, as separate from the Lias, is quite unnecessary, and it would be desirable that the term Oolite should be used only as a lithological appellation for a particular kind of rock, though there can be no objection to the retention of such compound names as Inferior Oolite and Great Oolite for groups which are chiefly composed of oolitic limestones. But let the name "Lower Oolites" be banished from our text-books. I can recollect the time when it was a trouble to remember that Inferior Oolite was not the same as Lower Oolite, and I cannot but think that the abolition of this possible source of confusion would be a benefit to young students of geology.

I feel confident that the divisions or stages of Upper, Middle, and Lower Jurassic will be ultimately accepted, but I ventuire to differ from Mr. Blanford in the manner of grouping the minor subdivisions under these heads.

The Lower Jurassic is of course synonymous with the Lias. The Middle stage should, in my view, comprise the overlying beds up to and no farther than the Cornbrash, and should certainly not include the Oxford Clay. The Cornbrash is a well-marked and nearly continuous horizon in England, and forms the natural summit to a group which is essentially composed of oolitic limestones. With the Oxford Clay, which includes the Kelloway rock near its base, begins a series which is essentially argillaceous or 